\title{
Effect of Saw Dust Ash and Eggshell Powder on the Properties of Cement Blends
}

\author{
Olubajo Olumide Olu \\ Department of Chemical Engineering, Abubakar Tafawa Balewa University, Bauchi, Nigeria
}

\section{Email address:}

ooolubajo@atbu.edu.ng

\section{To cite this article:}

Olubajo Olumide Olu. Effect of Saw Dust Ash and Eggshell Powder on the Properties of Cement Blends. American Journal of Construction and Building Materials. Vol. 4, No. 2, 2020, pp. 88-99. doi: 10.11648/j.ajcbm.20200402.16

Received: November 29, 2020; Accepted: December 11, 2020; Published: December 22, 2020

\begin{abstract}
The presence of calcium hydroxide $(\mathrm{CH})$ can pose deteriorating effect on the durability of the cement from the inclusion of Eggshell powder (ESP) into the cement matrix. The incorporation of supplementary cementitious materials (SCM) such as Saw dust ash (SDA) could improve the properties of ESP-cement blends by eliminating some undesirable effects at the later age. This paper tries to explore the effect of possibility of replacing eggshell powder (ESP) cement blend with SDA and cement replacement on the properties such as consistence, setting times, volume expansion and strength gain. Saw dust was calcined at $600^{\circ} \mathrm{C}$ for 1 hour and sieved with $90 \mu \mathrm{m}$ sieve to obtain SDA. Portland limestone cement CEM II A-L was blended with ESP was replaced with SDA between $0-20 \mathrm{wt} \%$ at $5 \mathrm{wt} \%$ intervals and $0-12.5 \mathrm{wt} \%$ at $2.5 \mathrm{wt} . \%$ interval for physical properties and mortar compressive strength using $50 \mathrm{~mm}$ cubes with mixing ratio 1:3:5 (water, binder and sand) respectively. The chemical analysis of SDA revealed a high silica content (56.81 wt.\%) with $\mathrm{SiO}_{2}+\mathrm{Al}_{2} \mathrm{O}_{3}+\mathrm{Fe}_{2} \mathrm{O}_{3}>70 \%$ (72.2 wt.\%), thus classified as Class F pozzolan according to ASTM C618 while ESP indicated a high lime content (48.5 wt.\%) and considered a filler. Results indicated an increase in the consistence and setting time of the ternary blends as ESP was replaced with SDA owing to the unburnt carbon present in the SDA as well as clinker diminution. Likewise, an increase in the cement replacement led to an increase in water consistence and setting times. The retarded setting times of SDA-ESP cement blends could be attributed to increased water required due to SDA's unburnt carbon whereas, ESP-cement blend produced accelerated setting times. A decrease in the volume expansion of the cement blends was observed as ESP was replaced with SDA which could be attributed to the decrease in the available lime while an increase in the volume expansion was also experienced as the cement replacement was increased from $0-20 \mathrm{wt} . \%$ at various SDA/SDA-ESP ratios from $0-0.8$ except ratio of 1.0. The mortar compressive strength of cement blended with ESP and SDA experienced an increase as curing age was lengthened despite clinker diminution. This enhanced strength could be linked with SDA's pozzolanic reactivity, provision of nucleation sites and formation of muscovite resulting in denser $\mathrm{CSH}$ with the optimal cement replacement observed at 5 wt. $\%$ with SDA/SDA-ESP ratio of 0.2 and 0.4 respectively.
\end{abstract}

Keywords: Saw Dust Ash, Eggshell Powder, Consistency, Setting Times, Soundness, Compressive Strength

\section{Introduction}

Concrete is a widely used building material and can be moulded in several geometrical configurations. Wastes generated from industrial and agricultural processes is estimated at more than 300 million tons per annum such as ESP and SDA could possess serious health implications and waste disposal issues. Proper usage of solid waste in order to free the environment and the society of the menace constituted by accumulated solid waste have been issues of serious concern to the developing countries especially
Nigeria. Global warming from the release of carbon-dioxide emissions, diminishing limestone global reserves, the growing demand for cement and the high energy cost in the cement production has driven researchers to sort for other alternatives [1]. One option is the use of SCMs in the construction sector. Researches are ongoing for other substitutes possibly through recycling of waste materials that possess pozzolanic properties to drive sustainability, to enhance the physico-mechanical properties of the cement blends with special performance requirements and maintaining the ecological balance [2]. Thus, promoting the development and 
production of blended cements and their behavior depends on the combination of the materials employed [3]. However, there is a new trend of making ternary blend that at least utilizes the combined effect of the two SCM clinker replacements, to provide a synergy between them [4]. Knowledge of the behavior of each of these SCMs, upon hydration, permits us to understand the action of the pozzolanas [5]. The significance of the technical understanding of setting process cannot be overemphasized in the construction industry by providing information if the SCM or filler is required for retarding or accelerating the setting time as well as enabling the scheduling of different stages in the construction of concrete operations ranging from transportation, placement, compaction and concrete finishing [6]. The factors that influence the setting time of cement include water-binder ratio, initial and curing conditions, cement composition and SCM type and content [7].

The ESP is been considered as an agricultural/ domestic waste which mainly comprises of limestone and tends to accelerate the setting time thereby enhancing the fresh and hardened properties of concrete/ mortar. The incorporation of SDA with ESP could provide a unique cement blend with interesting as well as enhanced cement properties. There is a dearth of literature on works conducted on ternary cement blends comprising of SDA and ESP to enhance the quality of cement. Studies indicated an increase in the setting time as the SDA content was gradually increased [8]. The retarded setting times of blended cement can be advantageous on the workability of the cement paste been prolonged for several applications especially in hot weather conditions. Whereas, the inclusion of ESP on the setting time has been observed to significantly improved surface area (enhanced fineness) and accelerate its setting time results. The binary effect of SDA and ESP indicated an increase and decrease in the setting times respectively as the replacement level was increased. Some industrial, agricultural, domestic waste/ by-products have been studied for use as SCM using fly ash, bottom ash, rice husk ash, SDA, ESP and metakaolin with various successes. Several studies have shown that the strength of ESP cement blends compared with ordinary Portland cement is more or less the same, or slightly increased [9-13]. This can be attributed to the fine particle size distribution of the ESP, thus enhancing the hydration rate of the clinker by the filler effect. Whereas, the negative effect on the mechanical properties was observed when the cement replacement with ESP which exceeds above $10 \mathrm{wt} \%$, resulting from diminution of reactive clinker component coupled with deteriorating hydration products [9]. Thus, the incorporation of SDA in ESP blended cement as a SCM could enhances the concrete performance since the SDA can be considered as highly activity pozzolanic material due to high amorphous silica content [14].

Nivedhitha and Sivaraja [9] exhibited an increase in the concrete compressive strength as the ESP content was increased from $2.5-15 \%$ at interval of $2.5 \%$ with its optimum concrete strength at cement replacement of $15 \%$ in comparison with conventional concrete. Kumar et al. [15] observed that cement replacement with coconut shell ash and ESP of $10 \%$ produced an enhanced strength in comparison with conventional concrete. Dhanalakshmi et al. [11] indicated a decrease in densities of the concrete cubes as the ESP content was increased with maximum compressive strength obtained at $7.5 \%$ cement replacement of ESP for all ages. The ESP concrete compressive strengths were found to be lower than the control concrete mix. Mastan and Kumar, [16] showed that fine aggregate replacement with ESP and FA produced better concrete strengths (compressive, splitting tensile and flexural) compared with normal concrete specimens at 7 days and especially beyond 28 days. Amarnath [12] researched on the influence of cement replaced with $0-15 \%$ ESP on concrete strength with the optimum strength determined at $5 \%$ ESP which was higher than normal concrete. He concluded that beyond $10 \%$, a lower concrete compressive strength was produced compares with control for all curing ages. Gowsika et al. [1] studied the effect of replacing cement with ESP from 5-30\% and obtained the optimum strengths at 5\% ESP which yielded similar concrete compressive and flexural strengths compared to plain ESP concrete. Similarly, Jayasankar et al. [13] investigated the effect of varying ESP content from $0-20 \%$ on the concrete compressive strength and produced the maximum compressive strength at 5\% cement replacement. Karthick et al. [17] investigated the replacement of fine aggregates with ESP from 0-50\% and observed that the concrete strengths diminished as the aggregates was gradually replaced with ESP. Praveen et al. [10] investigated the effect of employing ESP (10-30\%) and silica fumes (5-15\%) with optimum concrete strength observed at $15 \%$ ESP and observed an increase in the strength as silica fumes were incorporated. Mohamed et al. [18] indicated an increase in the ESP-concrete 7 days compressive strength as the ESP content was increased from $10-20 \%$, but beyond $15 \%$ led to a decrease in the strength. The ESP concrete strength for 10, 15 and 20\% were obtained as $22.18,23.37,19.58 \mathrm{~N} / \mathrm{mm}^{2}$ respectively in comparison to the control concrete of $18.15 \mathrm{~N} / \mathrm{mm}^{2}$.

Ogork and Ayuba [19] investigated the use of SDA as cement replacement material from $0-10 \%$ at $2 \%$ interval by weight of cement on both paste and concrete. The inclusion of SDA in cement resulted in an increase in the water consistence, setting times (retarder) and compressive strength, with the optimum obtained at 2\% SDA inclusion. Batt and Garg [20] investigated the effect of wood ash (WA) on volume expansion, flexural and compressive strengths and indicated an increase in the volume expansion as WA content increased while the flexural and compressive strength were enhanced up to 10 and $15 \%$ cement replacement beyond which any further increase resulted in diminished strength at various curing days 7, 28 and 56 days. The WA concrete were lower than the compressive and flexural strengths produced by control concrete. Chowdhury et al. [21] also investigated the effect of incorporating WA $0-20 \%$ on concrete compressive and flexural strengths with water-to-cement ratio of 0.4 and 0.45 . Results showed a decrease in both compressive and flexural strengths as WA content was increased, while their 
strengths increased with later age. Marthong [8] investigated the effect of cement replacement with SDA on concrete properties from $0-40 \%$ and found that the workability diminished, thus, requiring more water than control resulting in retarded setting times due to the low hydration rate in the paste containing SDA. The volume expansion also increased slightly as cement replacement was increased. The setting time and volume expansion of the SDA-concretes were seen to all fall within standards and the control' concrete compressive strength was greater compared to SDA concretes with the optimum strength at $10 \%$ SDA concrete. Raheem et al. [22] investigated the possibility of incorporating SDA in concrete with cement replacement from $5-25 \%$ at $5 \%$ interval and its effects on the workability and compressive strength of cement blends. Results indicated a decrease in the compressive strength and workability as cement replacement with SDA was increased. It was also observed that SDA-concrete produced lower compressive strengths at early stages whereas indicated enhanced strength up to 90 days with the study suggesting that $5 \%$ cement replacement with SDA gave the maximum strength gain. Sanjay and Rahul [23] studied the effect of replacing cement with 5,10,15 and $20 \%$ SDA on concrete compressive and flexural strengths for 7 and 28 days. Results indicated that 5 and $10 \%$ SDA concrete produced better strengths whereas at 15 and $20 \%$ SDA concrete produced lower concrete compressive strength compared to conventional concrete respectively. Obilade [24] and Malik et al. [25] both explored the use of SDA as partial cement replacement in concrete and concluded that the compressive strength diminished as SDA content increased while the compressive strength of SDA concrete increased as the curing time progressed. The later obtained the optimum SDA content at 5\% which was the maximum strength gain with the maximum allowable strength at $10 \%$ cement replacement.

In this study, inclusion of SDA in ESP cement blend as a pozzolana addition for cement paste is of considerable importance. The hydration products of cement include $\mathrm{CSH}$ and $\mathrm{CH}$; in which the presence of excess $\mathrm{CH}$ can pose deteriorating effect on the durability of the cement [26] from the inclusion of ESP into the cement matrix. Thus, incorporation of SDA as a pozzolanic addition in ESP cement blend can react with the excess $\mathrm{CH}$, thereby generating an additional calcium silicate hydrates $(\mathrm{CSH})$ phase thus producing concrete/ paste which is more homogeneous, denser and enhancing its strength despite diminution of clinker content [27, 28]. This study therefore, aims at investigating the effect of SDA and ESP on the physico-mechanical properties up to $20 \mathrm{wt} \%$ on the consistency and setting times while up to $12.5 \mathrm{wt} . \%$ for the mortar compressive strengths of ternary cement blends.

\section{Materials and Methods}

Saw dust was collected from the saw milling points at Yelwa, Bauchi State and carefully sorted to remove debris and sand. The saw dust was then sundried for 10 days to aid the burning process in a furnace at temperature of $600^{\circ} \mathrm{C}$ for 3 hours to obtain SDA. The resultant ash was then cooled and ground with mortar and pestle followed by size reduction with $90 \mu \mathrm{m}$ sieve. The Portland limestone cement (PLC) CEM II 42.5 R was obtained in Yelwa Bauchi while the standard sand was prepared according to Indian standards which was employed as fine aggregates. Tests were then conducted to determine the physical and chemical properties of the SDA, PLC and ESP while their chemical compositions were analyzed using X-ray fluorescence spectrometer (XRF) respectively. The required water of standard consistence, setting time and volume expansion and mortar compressive strength for the various cement blends (binary and ternary cements) and control were determined in accordance to ASTM C187 [29], ASTM C 191 [30], ASTM C 151-05 [31] and ASTM C109 [32] / IS: 4031 [33] respectively. SDA and ESP were employed to replace PLC at $0-12.5$ wt. $\%$ at interval of 2.5 wt. $\%$ by weight of cement to prepare mortars while control mortar without SDA and ESP with mixing ratio of 1:3:5 (water, binder and sand). The mixing was conducted by first placing the constituents and then water was poured in a laboratory mixer for 3-4 minutes to obtain a homogenous mortar mix. The specimens were then placed in the $50 \mathrm{~mm}$ cube mould and left for 24 hours. The mortar cubes were casted according to the specifications of IS 1031 [33] to determine the effect of ESP and SDA on the mortar compressive strength of various cement blends. The specimens were then demoulded and cured by immersing in normal water till the time of testing for 3, 7, 28 and 60 days respectively with compressive strength testing machine with capacity of $2000 \mathrm{KN} / \mathrm{s}$ with a loading rate of $3 \mathrm{KN} / \mathrm{s}$ was applied according to standards. The volume expansion (soundness) of the cement paste was determined through the Le Chatelier apparatus according to ASTM C 151 [31] and requiring minimum volume expansion after the cement sets. This volume expansion test was achieved by subjecting the Le Chatelier cylindrical mould containing the cement paste of diameter of $2 \mathrm{~mm}$ and height of $4 \mathrm{~mm}$ to curing with humid air for 24 hours, followed by subjecting it to steam pressure of $1 \mathrm{MPa}$ and temperature of $100^{\circ} \mathrm{C}$ for 15 minutes. The rationale behind subjecting the specimen to high temperature is to accelerate the hydration of magnesia, lime and expansion of the cement paste due to the formation of $\mathrm{CH}$ and $\mathrm{Mg}(\mathrm{OH})_{2}$ upon delayed hydration of free lime $(\mathrm{CaO})$ and Magnesium Oxide $(\mathrm{MgO})$ if present in the cement paste matrix. According to standards, the volume expansion of cement can be considered unsound if above $0.8 \%$ for various Portland cement types.

\section{Results and Discussion}

\subsection{Chemical Composition of the Starting Materials}

The chemical composition of SDA, ESP and PLC were tabulated in Table 1 while Table 2 presents the effect of incorporating ESP and/or SDA with cement on the consistence, 
both setting times and soundness of various cement blends.

Table 1. Chemical Composition of PLC, ESP and SDA.

\begin{tabular}{llll}
\hline Parameters & PLC wt.\% & ESP wt.\% & SDA wt. \% \\
\hline $\mathrm{SiO}_{2}$ & 23.87 & 9.48 & 0.19 \\
$\mathrm{SiO}_{2}$ (tot) & 12.48 & 1.00 & 56.81 \\
$\mathrm{Fe}_{2} \mathrm{O}_{3}$ & 1.96 & 0.10 & 4.39 \\
$\mathrm{CaO}$ & 43.44 & 48.88 & 11.34 \\
$\mathrm{MgO}$ & 0.75 & 0.75 & 0.81 \\
$\mathrm{Al}_{2} \mathrm{O}_{3}$ & 4.23 & 1.44 & 11.01 \\
$\mathrm{SO}_{3}$ & 1.04 & 0.65 & 0.96 \\
$\mathrm{~K}_{2} \mathrm{O}$ & 0.63 & 0.10 & 3.04 \\
$\mathrm{Na}_{2} \mathrm{O}$ & 0.09 & 0.11 & 0.54 \\
$\mathrm{P}_{2} \mathrm{O}_{5}$ & 0.17 & 0.42 & 0.20 \\
$\mathrm{Mn}_{2} \mathrm{O}_{3}$ & 0.10 & 0.01 & 0.10 \\
$\mathrm{TiO}_{2}$ & 0.19 & - & 0.99 \\
$\mathrm{LOI}$ & 34.91 & 47.99 & 9.79 \\
$\mathrm{Total}^{\mathrm{CaCO}}$ & 100.00 & 100.00 & 100.00 \\
\hline
\end{tabular}

Table 2. Water Consistence and Setting Times of SDA-ESP Cement Blends.

\begin{tabular}{|c|c|c|c|c|c|c|}
\hline S/No & Blends & SDA/SDA-ESP ratio & Water demand mm & Standard consistence \% & IST / FST (mins) & Soundness mm \\
\hline 1 & PLC & 0 & 90 & 30.0 & $185 / 280$ & - \\
\hline 2 & 5ESP & 0.0 & 108 & 36.0 & $59 / 196$ & 0.200 \\
\hline 3 & 4ESP1SDA & 0.2 & 99 & 33.0 & $72 / 202$ & 0.150 \\
\hline 4 & 3ESP2SDA & 0.4 & 111 & 37.0 & $82 / 214$ & 0.100 \\
\hline 5 & 2.5ESP2.5SDA & 0.5 & 114 & 38.0 & $98 / 228$ & 0.100 \\
\hline 6 & 2ESP3SDA & 0.6 & 120 & 40.0 & $110 / 237$ & 0.075 \\
\hline 7 & 1ESP4SDA & 0.8 & 126 & 42.0 & $123 / 240$ & 0.050 \\
\hline 8 & 5SDA & 1.0 & 132 & 44.0 & $135 / 251$ & 0.025 \\
\hline 9 & 10ESP & 0.0 & 114 & 38.0 & $44 / 200$ & 0.125 \\
\hline 10 & 8ESP2SDA & 0.2 & 120 & 40.0 & $51 / 205$ & 0.120 \\
\hline 11 & 6ESP4SDA & 0.4 & 126 & 42.0 & $58 / 212$ & 0.100 \\
\hline 12 & 5ESP5SDA & 0.5 & 129 & 43.0 & $64 / 219$ & 0.075 \\
\hline 13 & 4ESP6SDA & 0.6 & 135 & 45.0 & $70 / 225$ & 0.060 \\
\hline 14 & 2ESP8SDA & 0.8 & 141 & 47.0 & $86 / 230$ & 0.050 \\
\hline 15 & 10SDA & 1.0 & 147 & 49.0 & $112 / 246$ & 0.035 \\
\hline 16 & $15 \mathrm{ESP}$ & 0.0 & 126 & 42.0 & $47 / 159$ & 0.075 \\
\hline 17 & 12ESP3SDA & 0.2 & 132 & 44.0 & $49 / 170$ & 0.050 \\
\hline 18 & 9ESP6SDA & 0.4 & 141 & 47.0 & $53 / 182$ & 0.025 \\
\hline 19 & 7.5ESP7.5SDA & 0.5 & 147 & 49.0 & $56 / 198$ & 0.015 \\
\hline 20 & 6ESP9SDA & 0.6 & 153 & 51.0 & $60 / 207$ & 0.010 \\
\hline 21 & 3ESP12SDA & 0.8 & 156 & 52.0 & $64 / 218$ & 0.005 \\
\hline 22 & $15 \mathrm{SDA}$ & 1.0 & 162 & 54.0 & $87 / 240$ & 0.005 \\
\hline 23 & 20ESP & 0.0 & 141 & 47.0 & $79 / 225$ & 0.050 \\
\hline 24 & 16ESP4SDA & 0.2 & 147 & 49.0 & $39 / 108$ & 0.025 \\
\hline 25 & 12ESP8SDA & 0.4 & 153 & 51.0 & $43 / 119$ & 0.025 \\
\hline 26 & 10ESP10SDA & 0.5 & 159 & 53.0 & $45 / 131$ & 0.015 \\
\hline 27 & 8ESP12SDA & 0.6 & 165 & 55.0 & $48 / 142$ & 0.010 \\
\hline 28 & 4ESP16SDA & 0.8 & 174 & 58.0 & $50 / 155$ & 0.005 \\
\hline 29 & 20SDA & 1.0 & 183 & 61.0 & $61 / 168$ & 0.005 \\
\hline
\end{tabular}

The PLC is composed of Lime $(\mathrm{CaO})$ content (43.44 wt.\%), Silica $\left(\mathrm{SiO}_{2}\right)\left(12.48\right.$ wt.\%) with small Iron Oxide $\left(\mathrm{Fe}_{2} \mathrm{O}_{3}\right)$ content (1.96 wt.\%), Alumina $\left(\mathrm{Al}_{2} \mathrm{O}_{3}\right)$ content (4.23 wt.\%), Magnesium oxide (MgO) content (0.75 wt.\%), Sulphur trioxide $\left(\mathrm{SO}_{3}\right)$ content $\left(1.04\right.$ wt.\%) Sodium oxide $\left(\mathrm{Na}_{2} \mathrm{O}\right)$ content $\left(0.09\right.$ wt.\%), Potassium oxide $\left(\mathrm{K}_{2} \mathrm{O}\right)$ content $(0.63$ wt.\%) and Loss on ignition (LOI) of $34.91 \mathrm{wt} . \%$ according to ASTM C618-12 [35]. Chemical analysis revealed that the cement employed was classified as CEM II A-L 42.5R composed of four major oxides greater than $85 \mathrm{wt} \%$ with $\mathrm{Fe}_{2} \mathrm{O}_{3}, \mathrm{MgO}, \mathrm{Al}_{2} \mathrm{O}_{3}, \mathrm{SO}_{3}, \mathrm{~K}_{2} \mathrm{O}$ except $\mathrm{CaO}$ and $\mathrm{SiO}_{2}$ which fell within the approximate amount for Portland cement. The cement employed is a type II- A-L cement indicating that ordinary Portland cement is blended with $5-10 \%$ limestone while SDA chemical composition revealed a high silica content of 56.81 wt.\% and contains a significantly high alumina content of 11.01 wt. $\%, \mathrm{Fe}_{2} \mathrm{O}_{3}$ content of 4.39 wt. $\%$ and a low $\mathrm{MgO}$ content of 0.81 wt.\%. The SDA can be considered as a class $\mathrm{F}$ pozzolan according to ASTM C618 [34], since summation of $\mathrm{SiO}_{2}, \mathrm{Al}_{2} \mathrm{O}_{3}$ and $\mathrm{Fe}_{2} \mathrm{O}_{3}$ gave 72.22 wt.\% which is more than $70 \mathrm{wt} . \%$, while the $\mathrm{SO}_{3}$ content of $0.96 \%$ ( 5 wt. \% max) and a LOI of 9.79 wt.\% was observed. 
The specific gravity of PLC, ESP and SDA was obtained from the density bottle test as $2.99,2.47$ and 2.04 respectively. The SDA is a byproduct material gotten from sawdust which contains high $\mathrm{SiO}_{2}$ content, specific surface area and pozzolanic reactivity. The SDA possesses a high $\mathrm{SiO}_{2}$ content of $56.81 \mathrm{wt} . \%$ in comparison to that of ESP of $0.99 \mathrm{wt} . \%$ while ESP comprised of 48.50 wt. $\%$ of $\mathrm{CaO}\left(\mathrm{CaCO}_{3}\right.$ content of 86.55 wt.\%) with other minor constituents such as $\mathrm{SiO}_{2}, \mathrm{MgO}$, $\mathrm{SO}_{3}$ and $\mathrm{P}_{2} \mathrm{O}_{5}$ which are similar to several researches [22, 52]. The effect of replacing cement with ESP and SDA from 5-20 wt.\% at interval of $5 \mathrm{wt} . \%$ at various SDA/SDA-ESP ratios ranging from $0-1.0$ on the water consistence, setting times and soundness were determined.

\subsection{Water Consistency of Cement Blends}

\subsubsection{Effect of SDA/SDA-ESP ratio on the Water Consistence of Cement Blends}

Figure 1 illustrates the effect of SDA/SDA-ESP ratio on the water consistence of various cement blended with SDA and/or ESP. An increase in the water consistence of the cement blends was experienced as ESP content was gradually replaced with SDA at various cement replacement from 5 - 20 wt.\% as shown in Figure 1. This increase could be attributed to the unburnt carbon available in the SDA or due to its narrow particle size distribution, thus, requiring more water to achieve consistence as SDA content was increased.

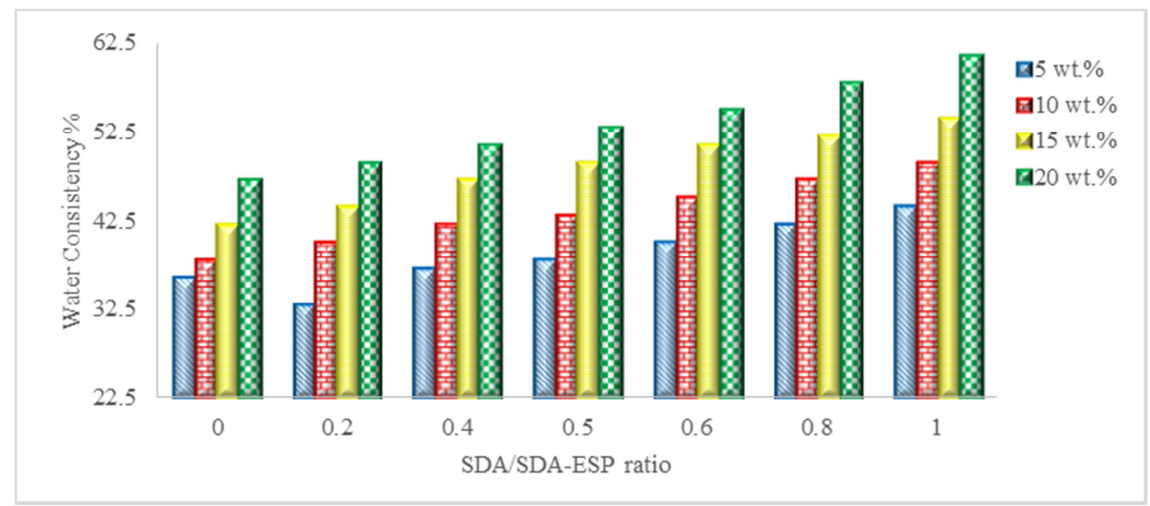

Figure 1. Variation in SDA/SDA-ESP ratio on the water consistency of cement blends for various cement replacement

\subsubsection{Effect of Cement replacement on the Water Consistency of Cement Blends}

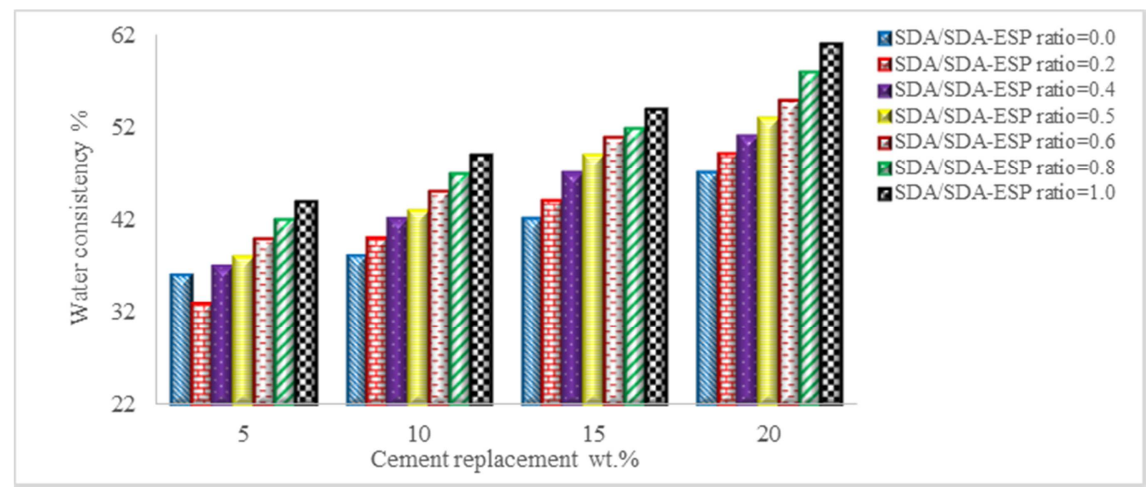

Figure 2. Variation in cement replacement on the water consistence of cement blends for various SDA/SDA-ESP ratios.

Figure 2 indicates the water consistence as a function of the cement replacement at various SDA/SDA-ESP ratios. An increase in the water consistence of SDA-ESP cement blends at various SDA/SDA-ESP ratios between $0-1$ as the cement replacement was increased from 5 - $20 \mathrm{wt} . \%$. This increase could be attributed to the unburnt carbon present and porous nature of SDA similar with Kaya [35] and Olubajo and Osha [36]. Another reason is the diminution of the clinker content by cement replacement with either SDA and/or ESP.

\subsection{Initial and Final Setting Times of Cement Blends}

\subsubsection{Effect of SDA/SDA-ESP Ratio on the Both Setting Times of Cement Blends}

Figures 3 and 4 depicts the effect of replacing cement with
SDA or/and ESP described by the SDA/SDA-ESP ratio and cement replacement on the initial and final setting times of cement blends respectively. Both setting time of the cement blends experienced a retardation as the SDA/SDA-ESP ratio was increased (increase in the SDA relative to ESP) at cement replacement of $5 \mathrm{wt} . \%$ while at cement replacement of 10, 15 and $20 \mathrm{wt} . \%$, the initial setting time experienced an initial acceleration between SDA/SDA-ESP ratio of 0 and 0.2 , beyond which resulted in a retardation in initial setting time as SDA content was increased from $0.2-1.0$. These retardations could be attributed to either the diminution of the clinker content (decrease in $\mathrm{C}_{2} \mathrm{~S}$ content) or the unburnt carbon present in the SDA resulting in an increase in the water for consistence and consequently elongated setting times [35, 36]. 
On the other hand, the accelerated setting time could be related to the available lime present in both ESP and SDA coupled with the enhanced surface area of the cementitious materials. Olubajo and Osha [36], Bonavetti [37], Soroka and Setter [38], Péra et al. [39] and Ramachandran and Zhang [40], all suggested that the provision of nucleation sites via production of $\mathrm{CH}$ crystals at the early hydration stage, thus enhancing the hydration of calcium silicates, and consequently leading to accelerated setting time of cements at the early age.

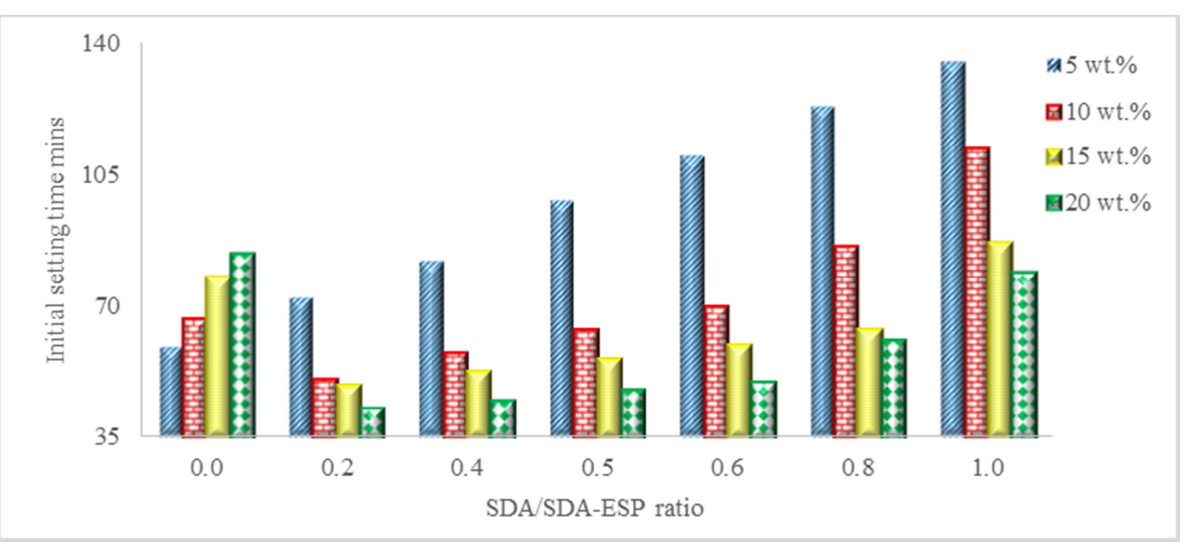

Figure 3. Effect of SDA/SDA-ESP ratio on the initial setting time of cement blends at various cement replacements.

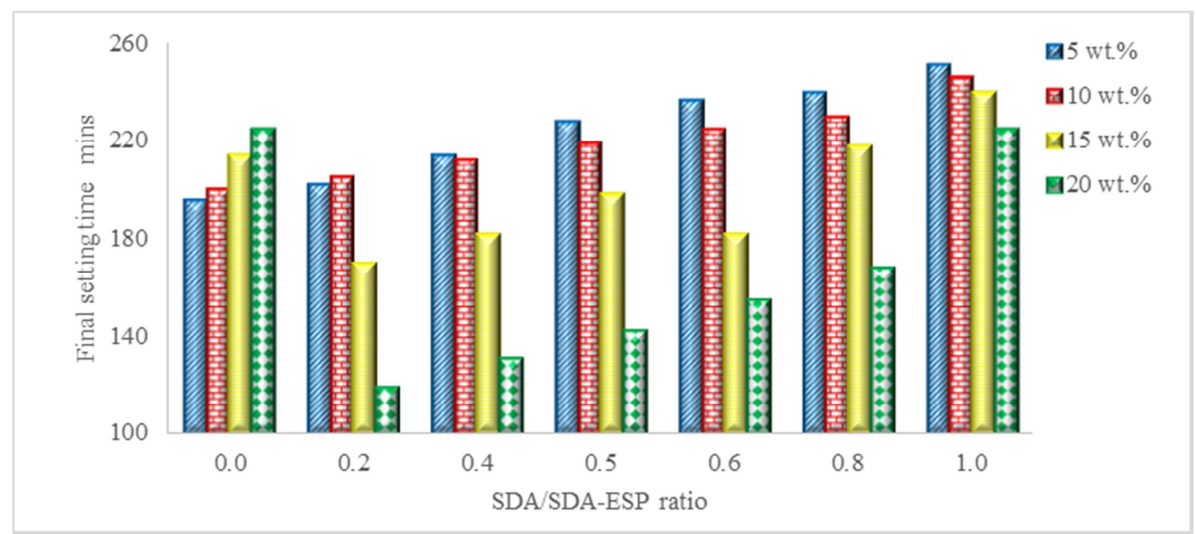

Figure 4. Effect of SDA/SDA-ESP ratio on the final setting time of cement blends at various cement replacements.

Lothenbach et al. [41], De Weerdt et al. [42], Barker and Cory [43] and Kakali et al. [44] investigated the effect of incorporating limestone which is similar to ESP in OPC matrix and observed that the hydrate assemblages of the cement matrix were affected by delayed transformation of ettringite to monosulfate especially at the early age with hydration rate of $\mathrm{C}_{3} \mathrm{~S}$ significantly enhanced. According to Ogork and Ayuba [19], obtained similar trends of an increase in both the water demand and setting times of SDA cement blends was observed as the SDA content was gradually increased from $0-10 \mathrm{wt} . \%$ at intervals of $2 \mathrm{wt} . \%$. Other reasons for the retarded setting time of cement blends could be due to the hydration of $\mathrm{MgO}$ present in the SDA to form tiny $\mathrm{Mg}(\mathrm{OH})_{2}$ crystals which tend to inhibit further hydration of the cement grain by envelopment as suggested by Olubajo et al. [45] and Deng [46]. It was also observed that SDA-ESP-cement blends required more water to achieve standard consistence which experienced accelerated setting times instead of elongated setting time in comparison with PLC control. This accelerated setting times experienced could be attributed to the presence of lime in SDA and ESP composition which affects the hydration assembly by delaying ettringite transformation to monosulfate especially at the early age $[28,41,42]$.

\subsubsection{Effect of Cement Replacement on the Both Setting Times of Cement Blends}

Similarly, the effect of cement replacement on both initial and final setting times of cement blends as ESP was replaced with SDA described by various SDA/SDA-ESP ratios illustrated in Figures 3 and 4 respectively. The setting times of cement blends experienced accelerations for all SDA/SDA-ESP ratios except 0 (ESP-cement blend) as the cement replacement was increased from 5-20 wt.\%. The retarded setting times of ESP cement produced at SDA/SDA-ESP ratio $=0$ agrees with findings by Amarnath et al. [12] and Gowsika et al. [1] except for higher cement replacement beyond $15 \mathrm{wt}$.

$\%$ resulted in setting time accelerated. This retarded setting times could be attributed to the delay in the transformation of ettringite to monosulfate during $\mathrm{C}_{3} \mathrm{~A}$ hydration which is dependent on the available lime in the cement matrix. Another reason could be due to the wide particle size distribution from the inclusion of ESP and SDA in cement. According to Deng [46] that the presence of $\mathrm{MgO}$ in ESP, thus results in the 
inhibition of blended cement hydration resulting in decelerated setting times.

\subsection{Soundness or Volume Expansion of Cement Blends}

\subsubsection{Effect of SDA/SDA-ESP Ratio on the Soundness of Cement Blends}

Figure 5 illustrates the effect of replacing ESP content with SDA (SDA/SDA-ESP ratio) at various cement replacement from $5-20$ wt. $\%$ at intervals of 5 wt. $\%$ on the volume expansion of SDA-ESP-cement blend. A gradual decrease in the volume expansion (soundness) was experienced at $5 \mathrm{wt} . \%$ as the ESP was gradually replaced with SDA content (an increase in SDA/SDA-ESP ratio from 0 to 1.0). The decrease in the volume expansion could be attributed to the diminishing of the available lime due to ESP replacement with SDA owing to the fact that ESP contains high lime content of $87.24 \mathrm{wt} . \%$.

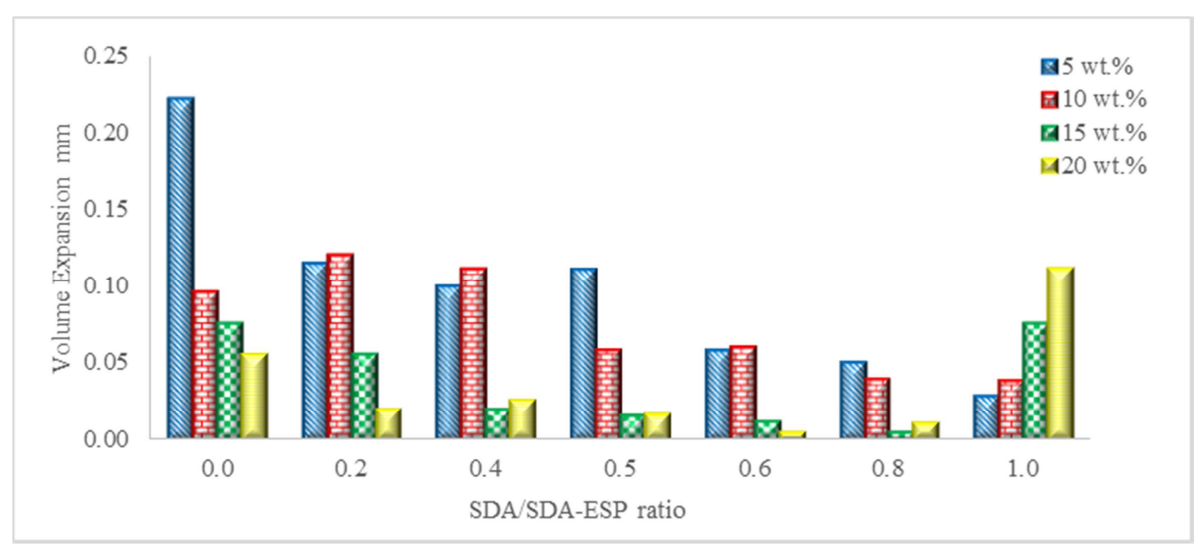

Figure 5. Effect of SDA/SDA-ESP ratio on the soundness of cement blends at various cement replacements.

Similar trend of a reduction in the volume expansion was experienced as ESP content was gradually replaced by SDA content at cement replacement of 10,15 and $20 \mathrm{wt} . \%$ for SDA/SDA-ESP ratio up to 0.8 . Whereas beyond SDA/SDA-ESP ratio of 0.8 led to an increase in the volume expansion (unsoundness of cement) which could be due to presence of alkaline oxides such as sodium oxide $\left(\mathrm{Na}_{2} \mathrm{O}\right)$ and potassium oxide $\left(\mathrm{K}_{2} \mathrm{O}\right)$ present in the SDA.

\subsubsection{Effect of Cement Replacement on the Soundness of Cement Blends}

Figure 5 also shows the volume expansion of cement blends as a function of the cement replacement at various SDA/SDA-ESP ratios. It could be observed that the volume expansion of cement blends diminished for SDA/SDA-ESP ratio between $0-0.8$ as cement replacement was increased from 5-20 wt.\%. This reduction could be attributed to consumption of the available free lime in ESP which compensates the diminution of clinker content as well as its replacement with SDA. whereas, for SDA/SDA-ESP ratio of 1.0 resulted in an increase in the volume expansion of SDA-cement blends as the cement replacement was increased due to presence of $\mathrm{K}_{2} \mathrm{O}$ and $\mathrm{Na}_{2} \mathrm{O}$ available in the SDA.

\subsection{Mortar Compressive Strength of Cement Blends}

Table 3 presents the mortar compressive strength of SDAESP cement blends at various SDA/SDA-ESP ratios and various cement replacement levels for curing ages of 3, 7, 28 and 60 days respectively while Figures 6-9 illustrates the effect of SDA/SDA-ESP ratios, curing days and cement replacements on the mortar compressive strength of SDA-ESP-cement blend.

Table 3. Effect of curing days and SDA/SDA-ESP ratio on the mortar compressive strength of various cement blends.

\begin{tabular}{|c|c|c|c|c|c|c|}
\hline S/No & Cement blends & SDA/SDA-ESP ratio & 3 days $N / \mathrm{mm}^{2}$ & 7 days $\mathrm{N} / \mathrm{mm}^{2}$ & 28 days $\mathrm{N} / \mathrm{mm}^{2}$ & 60 days $\mathrm{N} / \mathrm{mm}^{2}$ \\
\hline 1 & PLC & 0.0 & 14.58 & 25.58 & 36.22 & 40.28 \\
\hline 2 & 2.5ESP & 0.0 & 13.60 & 18.20 & 24.80 & 38.50 \\
\hline 3 & 2ESP0.5SDA & 0.2 & 13.30 & 21.10 & 39.40 & 41.10 \\
\hline 4 & 1.5ESP1SDA & 0.4 & 14.00 & 17.30 & 25.40 & 36.10 \\
\hline 5 & 1.25ESP1.25SDA & 0.5 & 11.60 & 17.90 & 23.20 & 33.10 \\
\hline 6 & 1ESP1.5SDA & 0.6 & 12.00 & 18.10 & 30.80 & 32.50 \\
\hline 7 & $0.5 \mathrm{ESP} 2 \mathrm{SDA}$ & 0.8 & 12.20 & 18.50 & 30.00 & 32.50 \\
\hline 8 & $2.5 \mathrm{SDA}$ & 1.0 & 9.30 & 18.40 & 32.70 & 36.10 \\
\hline 9 & $5 \mathrm{ESP}$ & 0.0 & 12.80 & 19.20 & 25.40 & 32.60 \\
\hline 10 & 4ESP1SDA & 0.2 & 14.60 & 21.10 & 36.20 & 40.90 \\
\hline 11 & 3ESP2SDA & 0.4 & 12.50 & 21.60 & 28.30 & 32.90 \\
\hline 12 & 2.5ESP2.5SDA & 0.5 & 13.80 & 19.40 & 24.60 & 33.00 \\
\hline 13 & 2ESP3SDA & 0.6 & 12.50 & 19.70 & 40.70 & 41.60 \\
\hline 14 & 1ESP4SDA & 0.8 & 12.20 & 20.40 & 31.10 & 33.40 \\
\hline
\end{tabular}




\begin{tabular}{|c|c|c|c|c|c|c|}
\hline S/No & Cement blends & SDA/SDA-ESP ratio & 3 days $N / \mathrm{mm}^{2}$ & 7 days $N / \mathrm{mm}^{2}$ & 28 days $\mathrm{N} / \mathrm{mm}^{2}$ & 60 days $N / \mathrm{mm}^{2}$ \\
\hline 15 & 5SDA & 1.0 & 9.60 & 14.70 & 27.10 & 31.50 \\
\hline 16 & 7.5ESP & 0.0 & 12.70 & 21.30 & 33.10 & 40.60 \\
\hline 17 & 6ESP1.5SDA & 0.2 & 12.30 & 22.50 & 34.80 & 42.70 \\
\hline 18 & 4.5ESP3SDA & 0.4 & 12.10 & 20.70 & 30.00 & 35.40 \\
\hline 19 & 3.75ESP3.75SDA & 0.5 & 12.70 & 20.30 & 28.00 & 37.90 \\
\hline 20 & 3ESP4.5SDA & 0.6 & 13.50 & 21.00 & 29.10 & 32.20 \\
\hline 21 & 1.5ESP6SDA & 0.8 & 14.20 & 21.00 & 26.20 & 36.10 \\
\hline 22 & $0.75 \mathrm{SDA}$ & 1.0 & 9.60 & 10.00 & 20.70 & 28.60 \\
\hline 23 & 10ESP & 0.0 & 11.90 & 20.20 & 30.10 & 34.30 \\
\hline 24 & 8ESP2SDA & 0.2 & 14.00 & 20.20 & 32.80 & 39.70 \\
\hline 25 & 6ESP4SDA & 0.4 & 11.90 & 19.20 & 29.00 & 33.90 \\
\hline 26 & 5ESP5SDA & 0.5 & 10.60 & 20.20 & 28.40 & 33.00 \\
\hline 27 & 4ESP6SDA & 0.6 & 11.90 & 20.20 & 29.40 & 32.40 \\
\hline 28 & 2ESP8SDA & 0.8 & 13.80 & 19.80 & 26.20 & 36.20 \\
\hline 29 & 10SDA & 1.0 & 9.00 & 12.60 & 22.30 & 36.20 \\
\hline 30 & 12.5ESP & 0.0 & 11.80 & 19.60 & 30.80 & 37.60 \\
\hline 31 & 10ESP2.5SDA & 0.2 & 13.60 & 19.60 & 33.90 & 44.20 \\
\hline 32 & 7.5ESP5SDA & 0.4 & 11.50 & 19.70 & 27.60 & 35.00 \\
\hline 33 & 6.25ESP6.25SDA & 0.5 & 11.20 & 18.80 & 26.40 & 28.00 \\
\hline 34 & 5ESP7.5SDA & 0.6 & 12.70 & 19.20 & 23.00 & 36.20 \\
\hline 35 & 2.5ESP10SDA & 0.8 & 13.80 & 18.10 & 27.50 & 30.50 \\
\hline 36 & $12.5 \mathrm{SDA}$ & 1.0 & 10.80 & 17.00 & 20.60 & 24.50 \\
\hline
\end{tabular}

Results indicated an increase in the mortar compressive strength of all the cement blends and control as the curing age was lengthened as illustrated in Figures 6-10 respectively. It could be observed that cement blends with higher ESP content produced better 3 days mortar compressive strengths than those with higher SDA content (especially for SDA/SDA-ESP ratios of $0,0.2$ and 0.4 respectively) for $2.5 \mathrm{wt} . \%$ cement replacement as illustrated in Figure 6. Similar trends were observed for LBPA-ESA cement blends according to Olubajo et al. [45]. The enhanced strength obtained by ESP cement blends at the early stage could be due to the provision of significant nucleation site as a result of $\mathrm{CH}$ formation along with availability of lime resulting in accelerated cement hydration rate and thus, early strength [28, 39].

Bonavetti et al. [37], Ikumapayi [47] and Spelta et al. [48] observed that the inclusion of ESP resulted in the formation of ettringite at the expense of monosulphate, thus an increase in the hydrate volume thereby, enhancing the compressive strength of ESP cement blends. A similar trend was observed for SDA/SDA-ESP at 0 and 0.2 which produced better 7 days strength. It could also be seen that the mortar compressive strength of cement blends for SDA/SDA-ESP ratio of 0.2 at 28 and 60 days and SDA/SDA-ESP ratio of 0 at 60 days produced cement blends with enhanced strength of $38.5 \mathrm{~N} / \mathrm{mm}^{2}, 41.1$ $\mathrm{N} / \mathrm{mm}^{2}$ and $39.14 \mathrm{~N} / \mathrm{mm}^{2}$ as against 28 and 60 days control strength of 36.22 and $40.28 \mathrm{~N} / \mathrm{mm}^{2}$ respectively. The enhanced strength obtained for $2.5 \mathrm{wt} . \%$ cement replacement could be related with pozzolanic reactions between the available lime after cement hydration along with lime inclusion from ESP and the silica available from SDA resulting in the formation of additional CSH (enhanced strength) despite clinker diminution.

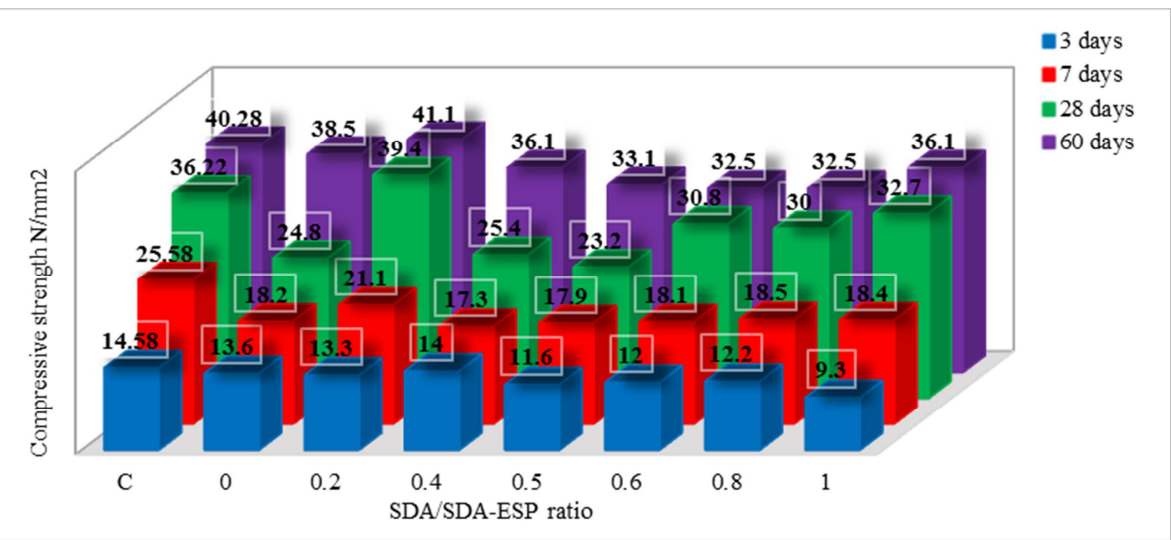

Figure 6. Variation of curing ages on the mortar compressive strength of cement blends for $2.5 \mathrm{wt} . \%$ cement replacement. 


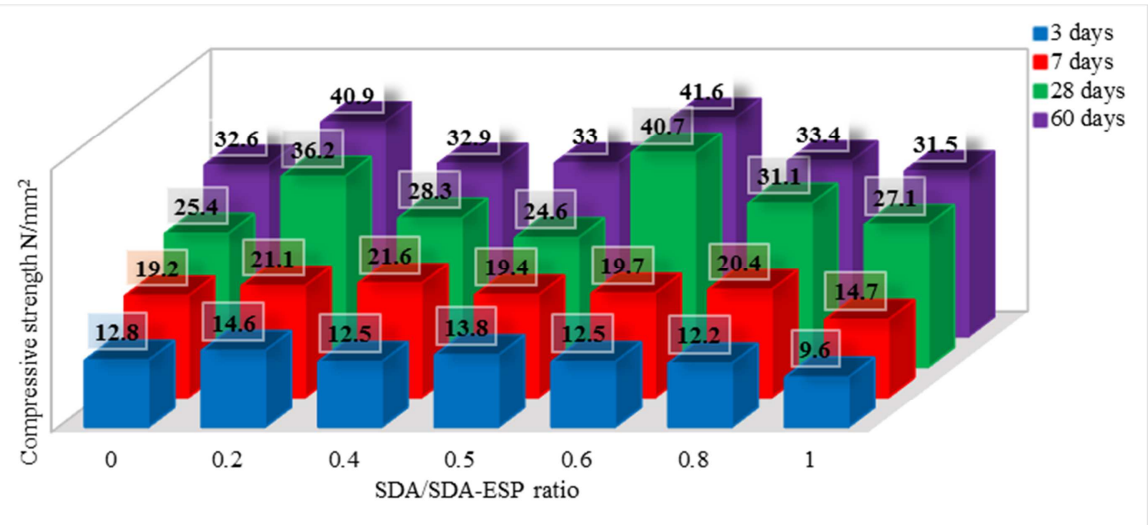

Figure 7. Variation of curing ages on the mortar compressive strength of cement blends for 5 wt.\% cement replacement.

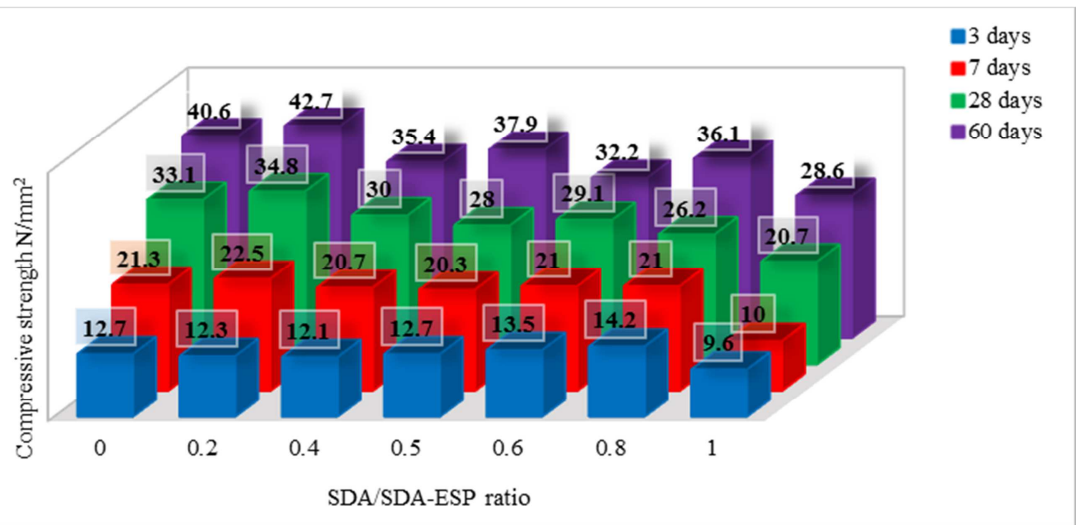

Figure 8. Variation of curing ages on the mortar compressive strength of cement blends for $7.5 \mathrm{wt} . \%$ cement replacement.

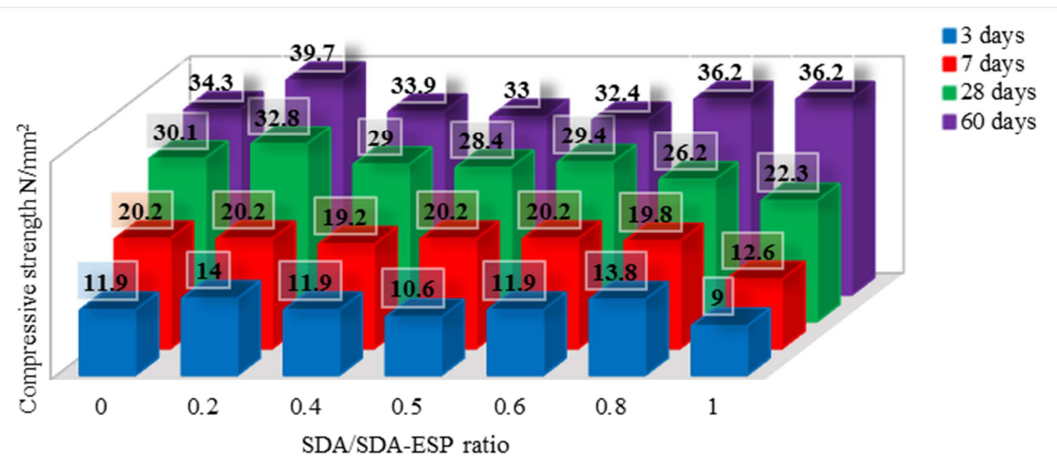

Figure 9. Variation of curing ages on the mortar compressive strength of cement blends for $10 \mathrm{wt} \%$ cement replacement.

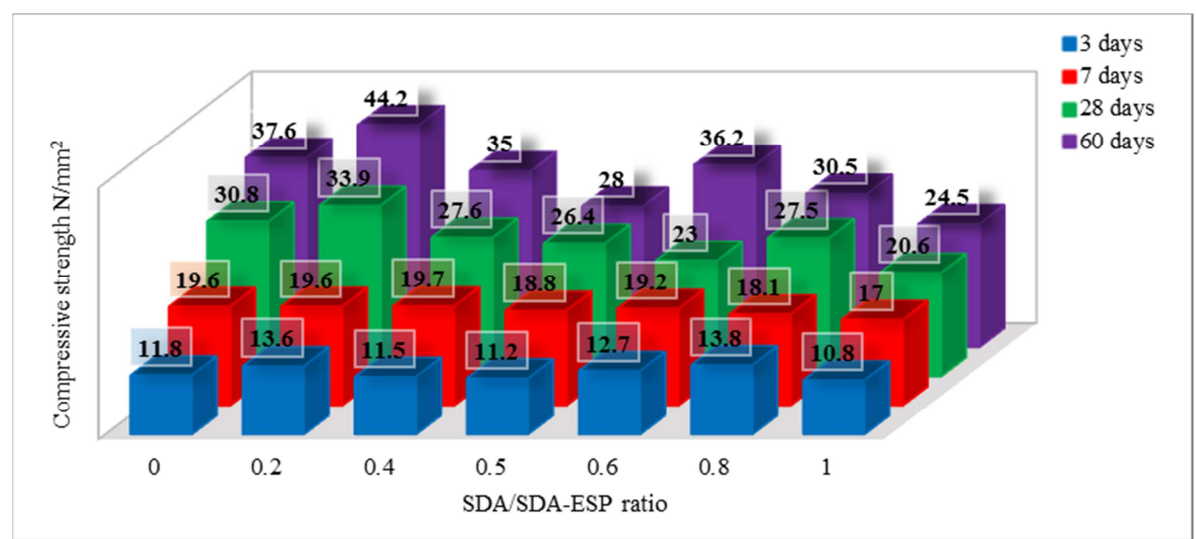

Figure 10. Variation of curing ages on the mortar compressive strength of cement blends for $12.5 \mathrm{wt} \%$ cement replacement. 
Other reasons suggested for the gradual strength gain despite clinker diminution is due to the formation of muscovite $\mathrm{K}_{2} \mathrm{Al}_{2} \mathrm{Si}_{6} \mathrm{Al}_{4} \mathrm{O}_{20}(\mathrm{OH})_{4}$ stemming from the inclusion of SDA resulting in an increase in potassium content $[45,49]$. Figures 6-10 showed that most of the mortar compressive strengths of the cement blends at 3, 7, 28 and 60 days beyond $2.5 \mathrm{wt} \%$ replacement were either slightly or significantly lower than the control except for cement blends with $5 \mathrm{wt} . \%$ cement replacement for SDA/SDA- ESP ratio of 0.2 and 0.6 which produced enhanced 28 and 60 days compressive strengths of 36.2 and $40.9 \mathrm{~N} / \mathrm{mm}^{2} ; 40.7$ and $41.6 \mathrm{~N} / \mathrm{mm}^{2}$ against control compressive strength of 36.22 and 40.28 $\mathrm{N} / \mathrm{mm}^{2}$ respectively. Whereas, cement blends with $7.5 \mathrm{wt} \%$ cement replacement at SDA/SDA- ESP ratios of 0 and 0.2 produced a better 60 days compressive strength of 40.6 and $42.7 \mathrm{~N} / \mathrm{mm}^{2}$ against control compressive strength of 40.28 $\mathrm{N} / \mathrm{mm}^{2}$, while cement blends with 12.5 wt. $\%$ cement replacement with SDA/SDA - ESP ratio of 0.2 produced an enhanced 60 days compressive strength of $44.2 \mathrm{~N} / \mathrm{mm}^{2}$ as against control compressive strength of $40.28 \mathrm{~N} / \mathrm{mm}^{2}$. These enhanced strengths experienced at the later age of 28 and 60 days despite the high cement replacement with SDA and ESP (clinker diminution) is evidence that pozzolanic activity occurs due to production of more CSH. Similarly, for $5 \mathrm{wt} . \%$ cement replacement at SDA/SDA-ESP ratio of 0.6 produced enhanced strength possibly due to the formation of muscovite due to significant potassium oxide content according to Venkateswara et al. [50] and Olubajo et al. [45]. It could also be observed that several cement blends' compressive strengths experienced a slightly lower early strength gains in comparison with control despite clinker diminution which could be attributed to $\mathrm{CH}$ inclusion from lime present in ESP and SDA. This inclusion of lime results in the provision of more nucleation sites resulting in increased hydration rate according to $[28,39,40,51]$ especially at the early age between 3 and 7 days.

\section{Conclusion}

Chemical analysis revealed that the cement employed was classified as CEM II A-L 42.5R composed of four major oxides greater than 85 wt. $\%$ with $\mathrm{Fe}_{2} \mathrm{O}_{3}, \mathrm{MgO}, \mathrm{Al}_{2} \mathrm{O}_{3}, \mathrm{SO}_{3}$, $\mathrm{K}_{2} \mathrm{O}$ except $\mathrm{CaO}$ and $\mathrm{SiO}_{2}$ which fell within the approximate amount for Portland cement. SDA composition revealed a high silica content (56.81 wt.\%), high alumina content (11.01 wt.\%) and moderate $\mathrm{Fe}_{2} \mathrm{O}_{3}$ content (4.39 wt.\%) and considered as Class $\mathrm{F}$ pozzolan according to ASTM C618 (2008) since $\mathrm{SiO}_{2}+\mathrm{Al}_{2} \mathrm{O}_{3}+\mathrm{Fe}_{2} \mathrm{O}_{3}>70 \%$ (72.2 wt.\%) whereas ESP classified a filler with high lime content (48.50 wt.\%) and $\mathrm{CaCO}_{3}$ content of 86.55 wt.\%. An increase in the cement replacement of ESP content with SDA content resulted in an increase in the water consistence of the cement blends which could be attributed to the presence of unburnt carbon in SDA and diminution of the clinker content. The cement blends also experienced a retardation in their setting time as the ESP was gradually replaced with SDA for SDA/SDA-ESP ratio from
$0.2-1.0$ which could be attributed to the increase in water required due to the unburnt carbon present in SDA whereas an acceleration in the setting time was observed as the cement replacement was increased from $0-25$ wt. $\%$ for all SDA/SDA-ESP ratios except 0 . The volume expansion of the cement blends experienced a decrease as ESP content was replaced with SDA, and this reduction in the volume expansion could be due to the decrease in ESP content which mainly contains lime whereas the volume expansion of ESP-SDA-cement blends decreased as the cement replacement was increased at a given SDA/SDA-ESP ratio between $0-0.8$ whereas the volume expansion of SDA-cement blends experienced an increase as the cement replacement at SDA/SDA-ESP ratio of 1.0. The increase in the volume expansion of SDA cement blends and decrease in the volume expansion of ESP cement blends could be due to variation in the available lime present in both blends respectively. The mortar compressive strength of cement blended with ESP and SDA increased as curing age was lengthened. This enhanced strength of the ESP-SDA cement blend despite clinker diminution could be attributed to either provision of nucleation sites, pozzolanic activity between the silica present in SDA and available lime present in ESP leading to production of denser $\mathrm{CSH}$ or formation of muscovite from the presence of Potassium Oxide in SDA. Cement blends with enhanced strength at 28 and 60 days compared to control include; 2ESP0.5SDA $\left(39.4 \mathrm{~N} / \mathrm{mm}^{2}\right.$, $\left.41.10 \mathrm{~N} / \mathrm{mm}^{2}\right), 4 E S P 1 S D A\left(36.2 \mathrm{~N} / \mathrm{mm}^{2}, 40.9 \mathrm{~N} / \mathrm{mm}^{2}\right)$, 2ESP3SDA (40.7 N/mm $\left.2,41.60 \mathrm{~N} / \mathrm{mm}^{2}\right), 7.5 \mathrm{ESP}$ (40.60 $\left.\mathrm{N} / \mathrm{mm}^{2}\right), 6 \mathrm{ESP} 1.5 \mathrm{SDA}\left(42.70 \mathrm{~N} / \mathrm{mm}^{2}\right)$ and 10ESP2.5SDA $\left(44.20 \mathrm{~N} / \mathrm{mm}^{2}\right)$ respectively.

Future work should include the monitoring of the hydration of ESP- cement blended with SDA employing various hydration monitoring equipment to better understand the hydration mechanism, since its inclusion showed promising prospect. Other ashes could be incorporated in order to enhance its cement properties. It can be recommended that ESP cement blended with SDA at SDA/SDA-ESP ratios of 0.2 and 0.6 at cement replacement of 5-7.5 wt.\% be investigated using various cement hydration techniques.

\section{Acknowledgements}

The author is grateful for the financial support from TETFUND to undertake this Institution Based Research while Ashaka Cement Plc., Nigeria and Department of Chemical Engineering and Civil Engineering of Abubakar Tafawa Balewa University, Bauchi, Nigeria for providing infrastructure, facilities and support to this research.

\section{References}

[1] Gowsika, D., Sarankokila, S., and Sargunan, K. (2014). Experimental investigation of egg shell powder as partial replacement with cement in concrete. International Journal of Engineering Trends and Technology (IJETT), 14 (2), 65-68. 
[2] Tiamiyu, I. A. (1997). Strength characteristics of cement-rice husk ash concrete. B. Eng Project, Department of Civil Engineering, Bayero University, Kano, pp. 52.

[3] Shiathas C., Muntasser, T. Z., and Nwaubani, S. O. (2000). A comparative study of the properties and durability of binary and ternary cementitious systems. pg. 3 .

[4] Damloft, J. S., Lukasik, J., Herfort, D., Sorrentino, D., and Gartner, E. M. (2008). Sustainable development and climate change initiatives. Cement and Concrete Research, 38 (2), $115-127$.

[5] Matawal, D. S. (2005). Application of ashes as pozzolana in mortar and concrete production. 1st National Academy Conference 31,

[6] Snelson, D., Wild, S., and O'Farrel, M. (2011). Setting times of Portland cement - metakaolin-fly ash blends. Taylor and Francis, 17, 55-62.

[7] Dave, N., Misra, A. K., Srivastava, A., and Kaushik, S. K. (2016). Setting time and standard consistency of quaternary binders: The influence of cementitious material addition and mixing. International Journal of Sustainable Built Environment, $1-7$.

[8] Marthong, C. (2012). Sawdust ash (SDA) as partial replacement of cement. International Journal of Engineering Research and Applications (IJERA), 2 (4), 1980-1985.

[9] Nivedhitha, M., and Sivaraja M., (2017) Experimental study on partial replacement of cement with coconut shell powder and egg shell powder. International Journal of Innovative Research in Science, Engineering and Technology, 6 (5), 8505-8511.

[10] Praveen, K. R., Vijaya, S. R., and Jose, V. B. (2015). Experimental study on partial replacement of cement with eggshell powder. International Journal of Innovations in Engineering and Technology (IJIET), 2 (5), 334-341.

[11] Dhanalakshmi, M., Sowmya, N. J., and Chandrashekar, A. (2015) A comparative study on egg shell concrete with partial replacement of cement by fly ash. International Journal of Engineering Research and Technology (IJERT). 4 (5), 1532-1539.

[12] Amarnath, Y. (2014). Properties of concrete with eggshell powder as cement replacement. Indian Concrete Journal pg. $1-10$.

[13] Jayasankar, R., Mahindran, N., and Ilangovan, R. (2010). Studies on concrete using fly ash, rice husk ash and egg shell powder. International Journal of Civil and Structural Engineering, Integrated Publishing Services. ISSN 0976-4399, $1(3), 362-372$.

[14] Al-Heaty, A. K. (2000). Controlling slump loss problems in ready mix high resistance concrete exposed to sever solutions", MSc. Thesis, University of Technology.

[15] Kumar, R. R., Mahendran, R., S., Nathan, S. G., Sathya, D. and Thamaraikannan K. (2017). An experimental study on concrete using coconut shell ash and egg shell powder. South Asian Journal of Engineering and Technology, 3 (7), 151-161.

[16] Mastan, S. A., and Kumar, V. R. P. (2015). Experimental study on concrete by partial replacement of fine aggregate with fly ash and egg shell powder. International Journal and Magazine of Engineering, Technology, Management and Research: A Peer Reviewed Open Access International Journal. 2 (2),
214-220.

[17] Karthick, J., Jeyanthi, R., and Petchiyamma, M. (2014). Experimental study on usage of egg shell as partial replacement for sand in concrete. International Journal of Advanced Research in Education Technology (IJARET) 1 (1) 7-10.

[18] Mohamed, A. M., Dinesh K. M., Milan C. J., and Vani, G., (2016) Replacement of cement using eggshell powder SSRG International Journal of Civil Engineering (SSRG - IJCE) 3 (3), $1-2$.

[19] Ogork, E. N., and Ayuba, S. (2014). Influence of sawdust ash (SDA) as admixture in cement paste and concrete. International Journal of Innovative Science, Engineering and Technology IJISET, 1 (10), 736-743.

[20] Batt, A. S., and Garg, A. (2017). Partial replacement of wood ash with ordinary Portland cement and foundry sand as fine aggregate. Journal of Civil Environ and Engineering, 7, 272. doi: 10.4172/2165-784X.1000272.

[21] Chowdhury, S., Maniar, A., and Suganya, O. M. (2015). Strength development in concrete with wood ash blended cement and use of soft computing models to predict strength parameters. Journal of Advanced Research, 6 (6), 907-913.

[22] Raheem, A. A., Olasunkanmi, B. S., and Folorunso, C. S. (2012). Saw dust ash as partial replacement for cement in concrete. Organization, Technology and Management in Construction and International Journal. 4 (2), 474-480.

[23] Sanjay, C., and Rahul, B. (2016). Study on saw dust ash as partial replacement with cement. International Journal of Engineering Technology Science and Research (IJETSR) 3 (4), 126-130.

[24] Obilade, I. O. (2014). Use of saw dust ash as partial replacement for cement in concrete. International Journal of Engineering Science Invention 3 (8), 36-40.

[25] Malik, M. I., Jan, S. R., Peer, J. A., Nazir, S. A. and Mohammad, K. F. (2015). Partial replacement of cement by saw dust ash in concrete a sustainable approach. International Journal of Engineering Research and Development 11 (2), 48-53.

[26] Shetty, M. (2005). Concrete technology: Theory and practice: S. Chand.

[27] Morsy, M., and Shebl, S. S. (2007). Effect of silica fume and metakaolin pozzolana on the performance of blended cement pastes against fire. Ceramics Silikaty, 5 (1), 40-44.

[28] Olubajo, O., Osha, O., El-Natafty, U., and Adamu, H. (2017). A study on Coal bottom ash and limestone effects on the hydration and physico-mechanical properties of ternary cement blends (Doctoral thesis). Abubakar Tafawa Balewa University, Bauchi, Nigeria.

[29] ASTM C 187, (2010). Standard test method for normal consistency of hydraulic cement. Annual Book of ASTM Standards.

[30] ASTM C 191 - 19 (2010). Standard test method for Time of Setting of hydraulic cement by Vicat Needle. Annual Book of ASTM Standards.

[31] ASTM C151. (2000). Standard test method for autoclave expansion of Portland cement, Document Number: ASTM C151-00, ASTM International. 
[32] ASTM C 109 (2008). Standard test method for compressive strength of hydraulic cement mortars. Annual Book of ASTM Standards.

[33] Bureau of Indian Standards. (1988). Methods of physical tests for hydraulic cement. Part 6: Determination of compressive strength of hydraulic cement (Other than masonry cement) (IS 4031: 1988). New Delhi: Bureau of Indian Standards.

[34] ASTM C 618 (2008). Standard specification for coal fly ash and raw or calcined natural pozzolan for use in concrete. Annual Book of ASTM Standards

[35] Kaya, A. (2010, September). A study on blended bottom ash cements (Master's thesis). Retrieved from http://etd.lib.metu.edu.tr/upload/12612504/index.pdf.

[36] Olubajo, O. O., and Osha, O. A. (2013). Influence of bottom ash and limestone powder on the properties of ternary cement and mortar. International Journal of Engineering Research and Technology 2 (7), 1201-1212 Available on website link: http://www.ijert.org.

[37] Bonavetti, V., Rahhal, V., and Irassar, E. (2001). Studies on the carboaluminate formation in limestone filler-blended cements. Cement and Concrete Research, 31 (6), 853-859. doi: 10.1016/s0008-8846(01)00491-4

[38] Soroka, I. and Setter, N. (1977). The effect of fillers on strength of cement mortars. Cement and Concrete Research, 7 (4), $449-456$.

[39] Péra, J., Husson, S., and Guilhot, B. (1999). Influence of finely ground limestone on cement hydration. Cement and Concrete Composites, 21 (2), 99-105.

[40] Ramachandran, V. S. and Zhang C. (1986). Thermal analysis of the $3 \mathrm{CaO} \cdot \mathrm{Al} 2 \mathrm{O} 3-\mathrm{CaSO} 4 \cdot 2 \mathrm{H} 2 \mathrm{O}-\mathrm{CaCO} 3-\mathrm{H} 2 \mathrm{O}$ system. Thermochimica acta, 106, 273-282.

[41] Lothenbach, B., Le Saout, G., Gallucci, E., and Scrivener, K. (2008). Influence of limestone on the hydration of Portland cements. Cement and Concrete Research, 38 (6), 848-860.

[42] De Weerdt, K., Kjellsen, K. O., Sellevold, E. and Justnes, H. (2011). Synergy between fly ash and limestone powder in ternary cements. Cement and Concrete Composites, 33 (1), 30-38.

[43] Barker, A., and Cory, H. P. (1991). The early hydration of limestone-filled cements. In Blended cements in construction. Papers presented at the International conference, University of Sheffield, UK, 9-12 September 1991.

[44] Kakali, G., Tsivilis, S., Aggeli, E., and Bati, M. (2000). Hydration products of $\mathrm{C} 3 \mathrm{~A}, \mathrm{C} 3 \mathrm{~S}$ and Portland cement in the presence of $\mathrm{CaCO}_{3}$. Cement and Concrete Research, 30 (7), 1073-1077.

[45] Olubajo O. O., Abubakar J., and Osha O. A. (2020) The effect of eggshell ash and locust bean pod ash on the compressive strength of ternary cement. Path of Science, 6 (3), 4001-4016. Available on website link: http://www.pos.org

[46] Deng, M. (1992). Mechanism of MgO expansion in cement. Cement and Concrete 22, 1-5.

[47] Ikumapayi, C. M. (2017). Crystal and microstructure analysis of pozzolanic properties of bamboo leaf ash and locust beans pod ash blended cement concrete. Journal of Applied Sciences and Environmental Management, 20 (4), 943. doi: 10.4314/jasem.v20i4.6.

[48] Spelta, J. S. de O., and Galdino, A. G. de S. (2018). Bioceramic composite: hen's eggshell characterization and main applications. Revista Ifes Ciência, 4 (1), 9-20. doi: 10.36524/ric.v4i1.323.

[49] Ojewumi, M., Ayomide, A., Obanla, O., Awolu, O., and Ojewumi, E. (2016). Pozzolanic properties of waste agricultural biomass - African locust bean pod waste. World Journal of Environmental Biosciences, 6 (3), 1-7.

[50] Venkateswara, R., Kontham, G., Venkata, R., and Chundupalli, S. (2011). Effect of potassium chloride $(\mathrm{KCl})$ on ordinary Portland cement (OPC) concrete. Research Journal of Chemical Sciences, 1 (2), 103-107.

[51] Tang, R. A. (2010, November). Compressive strength of normal strength concrete (NSC) using British Standard, Euro code and non-destructive test approaches (Bachelor's thesis). Retrieved from http://umpir.ump.edu.my/id/eprint/3297/1/TANG_JIAN AN.PDF.

[52] Mangi, S. A., Jamaluddin, N., Ibrahim, W. M. H., Mohamad, N., and Sohu S. (2017). Utilization of sawdust ash as cement replacement for the concrete production: A review. Engineering Science and Technology International Research Journal, 1 (3), 11-15. 